\title{
The anti-tumor NC1 domain of collagen XIX inhibits the FAK/ PI3K/Akt/mTOR signaling pathway through av $\beta 3$ integrin interaction
}

\author{
Jean-Baptiste Oudart ${ }^{1,2}$, Manon Doué ${ }^{1}$, Alexia Vautrin ${ }^{1}$, Bertrand Brassart ${ }^{1}$, Christèle \\ Sellier $^{1}$, Aurelie Dupont-Deshorgue ${ }^{1}$, Jean-Claude Monboisse ${ }^{1,2}$, François-Xavier \\ Maquart $^{1,2}$, Sylvie Brassart-Pasco ${ }^{1}$, Laurent Ramont ${ }^{1,2}$ \\ 'Université de Reims Champagne-Ardenne, CNRS UMR 7369 (Matrice Extracellulaire et Dynamique Cellulaire, MEDyC), \\ Reims, France \\ ${ }^{2} \mathrm{CHU}$ de Reims, Laboratoire Central de Biochimie, Reims, France
}

Correspondence to: Laurent Ramont, e-mail: Iramont@chu-reims.fr

Keywords: collagen XIX, NC1 domain, integrin, FAK/PI3K/AKt/mTOR, tumor invasion

Received: April 24, 2015

Accepted: November 14, 2015

Published: November 26, 2015

\section{ABSTRACT}

Type XIX collagen is a minor collagen associated with basement membranes. It was isolated for the first time in a human cDNA library from rhabdomyosarcoma and belongs to the FACITs family (Fibril Associated Collagens with Interrupted Triple Helices). Previously, we demonstrated that the NC1 domain of collagen XIX (NC1(XIX)) exerts anti-tumor properties on melanoma cells by inhibiting their migration and invasion. In the present work, we identified for the first time the integrin av $\beta 3$ as a receptor of NC1(XIX). Moreover, we demonstrated that NC1(XIX) inhibits the FAK/PI3K/Akt/mTOR pathway, by decreasing the phosphorylation and activity of the major proteins involved in this pathway. On the other hand, NC1(XIX) induced an increase of GSK3 $\beta$ activity by decreasing its degree of phosphorylation. Treatments targeting this central signaling pathway in the development of melanoma are promising and new molecules should be developed. NC1(XIX) seems to have the potential for the design of new anti-cancer drugs.

\section{INTRODUCTION}

Collagen XIX was isolated from human rhabdomyosarcoma cells in 1992 by Hidei Yoshioka, under the name of collagen Y [1]. According to its amino acid sequence, it was classified in the FACIT family (Fibril Associated Collagens with Interrupted Triple helices). This initial classification was confirmed by several groups $[2,3]$. In 1993, Myers et al. described a new collagen named RH COL [4] which turned out to be the same as collagen Y, so that, in 1994 the collagen XIX name replaced the two previous names [5]. Type XIX collagen has high homology with collagens IX, XII and XVI, in particular the presence of many well-conserved cysteine residues [6].

The type XIX collagen is a homotrimer of 400 $\mathrm{kDa}$, composed of the combination of three $112 \mathrm{kDa}$ $\alpha 1$ (XIX) chains. Each chain is encoded by a $250 \mathrm{Kbp}$ gene (encompassing 51 exons) located on chromosome 6 q12-q14 and consists of 1142 residues, with 5 collagenous domains (Col1 to Col5) interrupted by six non-collagenous domains (NC1 to NC6) [7, 8]. NC1(XIX) is a 19 amino acid peptide localized at the C-terminal end of the $\alpha 1$ (XIX) chain. Unlike other FACIT collagens, $\alpha 1$ (XIX) collagen chain has interchain and intrachain disulfide bonds which allow the formation of oligomers of different sizes [5, 8]. For our part, we have recently shown in the laboratory that the 19 amino acid NC1(XIX) forms intrachain disulfide bonds in solution [9].

Collagen XIX is ubiquitously expressed during embryogenesis where it is involved in the assembly of the extracellular matrix. In adults, its distribution is more restricted: vessels, skeletal muscle, spleen, prostate, kidney, liver, colon, placenta, breast, neurons and skin $[10,11]$. It is involved in embryogenesis, in muscle differentiation [12] and in the development of esophagus [13]. Mice lacking collagen XIX are not viable and die early, due to abnormalities in muscle development. More recently, collagen XIX was reported to play a role in the hippocampal synapses formation [14]. 
In 2003, Myers et al. demonstrated that collagen XIX disappears early in the development of invasive breast cancer even before invasive stages [11]. This was the first description of the possible involvement of this collagen in the control of tumor invasion. By analogy with other NC1 domains of basement membrane collagens, we hypothesized that $\mathrm{NC1}$ (XIX) could have anti-tumor effects and demonstrated that it was able to inhibit in vitro migration and invasion of melanoma cells and inhibited melanoma growth in vivo $[15,16]$. We also showed that plasmin, a key enzyme in tumor invasion, releases a peptide derived from the $\mathrm{NC} 1$ domain that has the same anti-tumor effects as the entire $\mathrm{NC1}$ domain [9].

Integrins are transmembrane receptors often involved in tumor invasion. They are heterodimeric molecules composed of two subunits, $\alpha$ and $\beta$ [17]. Antitumor matrikines were reported to bind integrin receptors but other receptor types are not excluded. For example, tumstatin (the NC1 domain of the $\alpha 3$ chain of collagen IV) binds the $\alpha v \beta 3$ and $\alpha 3 \beta 1$ integrins $[18,19,20]$, arresten (the $\mathrm{NC} 1$ domain of the $\alpha 1$ chain of collagen IV) binds the $\alpha 1 \beta 1$ integrin [21], canstatin (the $\mathrm{NC} 1$ domain of $\alpha 2$ chain of collagen IV) binds the $\alpha v \beta 3$ and $\alpha v \beta 5$ integrins [22], tetrastatin (the $\mathrm{NC} 1$ domain of the $\alpha 4$ chain of collagen IV) binds the $\alpha v \beta 3$ integrin [23] and endostatin (the $\mathrm{NC1}$ domain of the $\alpha 1$ chain of collagen XVIII) interacts with the $\alpha 3 \beta 1, \alpha 5 \beta 1$ and $\alpha \mathrm{V} \beta 3$ integrins $[24,25,26]$.

Many signaling pathways are involved in the different stages of melanoma development, as reported by Uddensky et al. Koo et al. have shown [27]. The FAK (Focal Adhesion Kinase) / PI3K (PhosphoInositide 3-Kinase) / Akt (proteine Kinase B) / mTOR (Mammalian Target Of Rapamycin) pathway is the most commonly involved signaling pathway. [28, 29]. This pathway is well characterized in melanoma carcinogenesis and involves a phosphorylation cascade well known in the literature [30] and often activated through integrin binding [27].

The aim of this work was to identify the receptor(s) of the $\mathrm{NC1}$ (XIX) domain on melanoma cells and to identify the involved signaling pathway that could explain its anti-tumor effects in melanoma. We demonstrated the involvement of $\alpha v \beta 3$ integrin and a decrease in the phosphorylation of the FAK/PI3K/Akt/mTOR signaling pathway.

\section{RESULTS}

\section{NC1(XIX) inhibits the migration of SK-MEL-28 melanoma cells}

Previous studies performed in our laboratory clearly demonstrated anti-tumor and anti-angiogenic activities of NC1(XIX). These results were confirmed on SK-MEL-28 melanoma cell line. In scratch wound assay, migration of SK-MEL-28 melanoma cells was significantly decreased after $\mathrm{NC1}(\mathrm{XIX})$ treatment (Figure 1A). NC1(XIX) inhibited melanoma cell migration by $47 \%(p<0.05)$,
$33 \%(p<0.05)$ and $31 \%(p<0.05)$ at 24,48 and $72 \mathrm{~h}$, respectively (Figure 1B).

\section{avß3 integrin specifically binds NC1(XIX)}

Integrins have been demonstrated to serve as receptors of several matrikines, such as tumstatin or endostatin. Since integrins require divalent cations to bind ligands, we investigated the effects of $\mathrm{Ca}^{2+}$, $\mathrm{Mg}^{2+}, \mathrm{Mn}^{2+}$ and EDTA on cell adhesion to NC1(XIX) (Figure 2). SK-MEL-28 cell adhesion to NC1(XIX) was significantly increased compared to the negative control, BSA $(p<0.001)$, whereas adhesion was similar to the positive control, fibronectin. Adhesion of SK-MEL-28 cells was significantly decreased in the presence of 5 mM EDTA $(p<0.001)$. Cell adhesion was significantly restored when $\mathrm{Ca}^{2+}$ and $\mathrm{Mg}^{2+}$ were added into the media in order to counteract EDTA effect $(p<0.001)$ (Figure 2A). Likewise, SK-MEL-28 cell adhesion to NC1(XIX) was significantly increased in the presence of $0.1 \mathrm{mM} \mathrm{Mn}^{2+}$ $(p<0.001)$ (Figure 2B). Taken together, these results suggest the involvement of a cation-dependent receptor in SK-MEL-28 adhesion to NC1(XIX).

SK-MEL-28 melanoma cells were preincubated with monoclonal antibody directed against human $\alpha v \beta 3$ integrin and then seeded in NC1(XIX) coated wells for $2 \mathrm{~h}$ at $37^{\circ} \mathrm{C}$. The addition of the $\alpha \mathrm{v} \beta 3$ integrin monoclonal blocking antibody significantly decreased cell adhesion compared to control $(p<0.001)$ (Figure $2 \mathrm{C}$ ), suggesting $\alpha v \beta 3$ integrin as a potential receptor for NC1(XIX).

SK-MEL-28 extracts were analyzed by affinity chromatography on a NC1(XIX)-Sepharose column. Proteins bound to the affinity column were eluted with increasing concentrations of $\mathrm{NaCl}(0.15,0.6$ and $1.0 \mathrm{M})$. Eluted samples were submitted to SDS-PAGE and analyzed by western blot. The $0.6 \mathrm{M}$ eluted samples revealed a band which matched the $105 \mathrm{kDa}$ band of the denaturated recombinant $\alpha v \beta 3$ integrin (Figure 2D). This result suggested an interaction between $\mathrm{NC1}$ (XIX) and $\alpha \mathrm{v} \beta 3$ integrin.

The interaction was confirmed in liquid phase binding assay. Recombinant $\alpha v \beta 3$ integrin was incubated with biotinylated NC1(XIX) peptide with or without excess of unlabeled NC1(XIX) peptide. Integrin-peptide complexes were precipitated using sepharose-streptavidin beads and revealed by western blot. As shown in Figure 2E, biotinylated $\mathrm{NC} 1$ (XIX) peptide specifically binds recombinant $\alpha \mathrm{v} \beta 3$ integrin (lane 1). The binding is reduced in the presence of unlabeled $\mathrm{NC1}$ (XIX) peptide (lane 2). Recombinant $\alpha \mathrm{v} \beta 3$ integrin was used as positive control (lane 3).

\section{$\mathrm{NC1}(\mathrm{XIX})$ colocalizes with $\alpha \mathrm{v} \beta 3$ integrin in SK-MEL-28 melanoma cells}

SK-MEL-28 melanoma cells were cultured on glass slides, fixed with paraformaldehyde and incubated with biotinylated $\mathrm{NC1}$ (XIX) peptide, unlabeled $\mathrm{NC1}$ (XIX) 
peptide. Immunofluorescence studies showed biotinylated NC1(XIX) peptide $(20 \mu \mathrm{M})$ (green) fixation on SKMEL-28 cell surface. Competition assay with 10 foldconcentrated NC1(XIX) peptide $(200 \mu \mathrm{M})$ completely abolished the biotinylated NC1(XIX) peptide labeling on SK-MEL-28 (Figure 3A). These data demonstrated the specificity of the NC1(XIX) peptide immunofluorescence fixation. As shown in Figure 3B, immunocytofluorescence microscopy analysis showed colocalization (yellow staining) between biotinylated $\mathrm{NC1}$ (XIX) peptide (green) and $\alpha v \beta 3$ integrin (red) which suggested that $\alpha v \beta 3$ integrin may be one of the NC1(XIX) SK-MEL-28 receptors.

Moreover, SK-MEL-28 melanoma cells were cultured on glass slides, fixed with paraformaldehyde and incubated with biotinylated $\mathrm{NC1}(\mathrm{XIX})$ peptide and anti- $\alpha v \beta 3$ integrin antibody (23C6). Competition assay with anti- $\alpha v \beta 3$ integrin antibody (23C6) abolished the biotinylated NC1(XIX) peptide labeling on SK-MEL-28 (Figure 3C).

\section{cRGDfV blocking peptide inhibits the NC1(XIX) binding on $\alpha \mathrm{v} \beta 3$ integrin}

SK-MEL-28 melanoma cells were preincubated with cRGDfV $\alpha v \beta 3$ blocking peptide and then seeded in $\mathrm{NC1}$ (XIX)-coated wells for $2 \mathrm{~h}$ at $37^{\circ} \mathrm{C}$. The addition of cRGDfV blocking peptide significantly decreased cell adhesion compared to control ( $p<0.001)$ (Figure 4A).
We characterized the expression of integrins at the cell surface and demonstrated the expression of the integrin $\alpha v \beta 3$ on the cells surface using flow cytometry (Supplementary Figure 1) and by immunocytofluorescence microscopy analysis (Supplementary Figure 2). Moreover, flow cytometry studies showed NC1(XIX) peptide $(100 \mu \mathrm{M})$ fixation on SK-MEL-28 cell surface. This binding was inhibited by the addition of cRGDfV blocking peptide or anti- $\alpha v \beta 3$ integrin antibody (23C6) (Figure 4B and 4C).

\section{NC1(XIX) decreases FAK ${ }^{\mathrm{Y} 861}$ phosphorylation, PI3K P85 ${ }^{\text {Y458 }}$ phosphorylation and PDK1 ${ }^{\text {s241 }}$ phosphorylation in SK-MEL-28 melanoma cells}

It is now well established that the FAK/PI3K/Akt/ mTOR pathway plays a critical role in the development of melanoma. SK-MEL-28 melanoma cells were incubated with $\mathrm{NC1}(\mathrm{XIX})$ for 1, 5, 15, 30 and $60 \mathrm{~min}$. Expression of total protein and correspondent phosphorylated protein were evaluated by western blot. FAK ${ }^{\mathrm{Y} 397}$ phosphorylation was not modified even after 60 min of incubation with $\mathrm{NC1}$ (XIX). Total FAK level and $\mathrm{FAK}^{\mathrm{Y} 397}$ / total FAK ratio remained also unchanged (Figure 5A). By contrast, as shown in Figure 5B, FAK ${ }^{\mathrm{Y} 861}$ phosphorylation decreased gradually after $1 \mathrm{~min}$ and $5 \mathrm{~min}$ of incubation with $\mathrm{NC1}$ (XIX), while total FAK level remained unchanged. The FAK $^{\mathrm{Y} 861}$ / total FAK ratio was decreased by $50 \%$ at $5 \mathrm{~min}$ and was progressively restored after $30 \mathrm{~min}$.
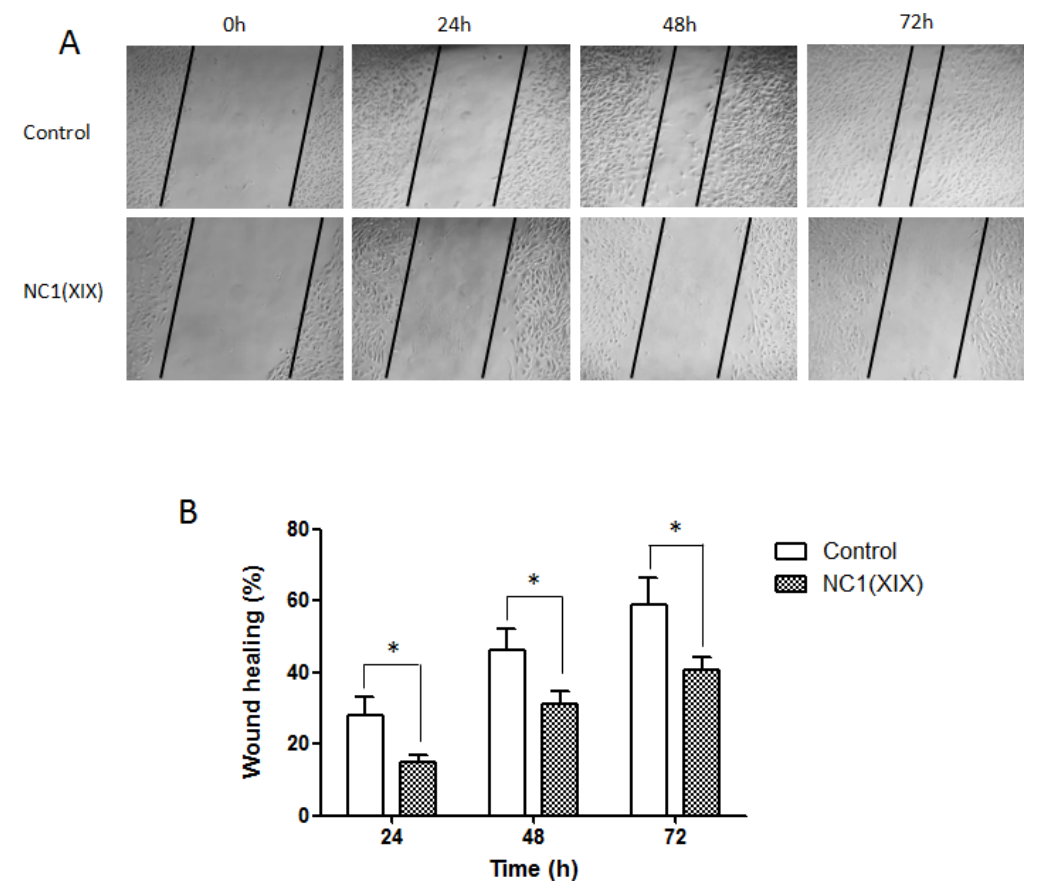

Figure 1: NC1(XIX) inhibits migration of SK-MEL-28 melanoma cells. (A) SK-MEL-28 cells were seeded in $12-$ well plates. Cell layer was scratched with a pipet tip and then incubated with or without $20 \mu \mathrm{M}$ of NC1(XIX) up to $72 \mathrm{~h}$ at $37^{\circ} \mathrm{C}$. Wound closure was measured by microscopy at $0,24,48,72 \mathrm{~h}$ respectively. (B) Wound closure was significantly delayed after NC1(XIX) treatment compared to control. Histogram represents the mean \pm SEM of 4 replicates. ${ }^{*}$ Significantly different from control $(* p<0.05)$. 
In the same conditions, Tyr458 phosphorylation of the PI3K p85 subunit decreased gradually from $1 \mathrm{~min}$ to 60 min of incubation, while total PI3K p85 level remained unchanged. The PI3K p85 ${ }^{\mathrm{Y} 458}$ / total PI3K p85 ratio was decreased by $20 \%$ at $5 \mathrm{~min}$ and $70 \%$ at $60 \mathrm{~min}$ (Figure $5 \mathrm{C}$ ). In the same way, $\mathrm{NC} 1(\mathrm{XIX})$ induced a decreased in PDK $1^{\text {S241 }}$ phosphorylation after 1 and 5 min of incubation, while total PDK1 level remained unchanged. The $\mathrm{PDK}^{\mathrm{S} 241}$ / total PDK1 ratio was decreased by $30 \%$ at $5 \mathrm{~min}$ and remained decreased for at least $60 \mathrm{~min}$ (Figure 5D).

\section{NC1(XIX) decreases Akt ${ }^{\mathrm{T} 308}$ phosphorylation, $\mathrm{Akt}^{\mathrm{S} 473}$ phosphorylation, mTOR ${ }^{\mathrm{S} 2448}$ phosphorylation, mTOR ${ }^{\mathrm{S} 2481}$ phosphorylation and GSK3 ${ }^{\mathrm{S9}}$ phosphorylation in SK-MEL-28 melanoma cells}

Akt is located at the crossroads of numerous signaling pathways and plays a key role in many biological activities. NC1(XIX) induced a decrease in $\mathrm{Akt}^{\mathrm{T} 308}$ phosphorylation from 1 to $30 \mathrm{~min}$ of incubation, while total Akt level remained unchanged. The $\mathrm{Akt}^{\mathrm{T} 308} /$ total Akt ratio decreased of $20 \%$ at $1 \mathrm{~min}$ and $50 \%$ at 15 and $30 \mathrm{~min}$ (Figure 6A). In the same way, $\mathrm{NC1}$ (XIX) also triggered a decrease in $\mathrm{Akt}^{\mathrm{S} 473}$ phosphorylation. The $\mathrm{Akt}^{\mathrm{S} 473}$ / total Akt ratio decreased of $30 \%$ at $60 \mathrm{~min}$ (Figure 6B). As shown in Figure 6C, $\mathrm{mTOR}^{\mathrm{S} 2448}$ phosphorylation decreased gradually from $15 \mathrm{~min}$ to $60 \mathrm{~min}$ of incubation with $\mathrm{NC1}$ (XIX), while total mTOR level remained unchanged. The $\mathrm{mTOR}^{\mathrm{S} 2448}$ / total $\mathrm{mTOR}$ ratio was decreased by $25 \%$ at $30 \mathrm{~min}$ and $60 \%$ after $60 \mathrm{~min}$ of incubation. In the same way, NC1(XIX) induced a decreased in $\mathrm{mTOR}^{\mathrm{S} 2481}$ phosphorylation after $15 \mathrm{~min}$. The $\mathrm{mTOR}^{\mathrm{S} 2481} /$ total mTOR ratio also decreased of $30 \%$ from 15 to $60 \mathrm{~min}$ of incubation (Figure 6D).

In the same conditions, Ser 9 phosphorylation of GSK $3 \beta$ decreased gradually from $30 \mathrm{~min}$ to $60 \mathrm{~min}$ of incubation, while total GSK3 $\beta$ level remained unchanged. The GSK $3 \beta^{\mathrm{S} 9}$ / total GSK3 $\beta$ ratio was gradually decreased by $30 \%$ at $30 \mathrm{~min}, 40 \%$ at $60 \mathrm{~min}$ and remained decreased by $30 \%$ at $360 \mathrm{~min}$ (Figure $6 \mathrm{E}$ ).
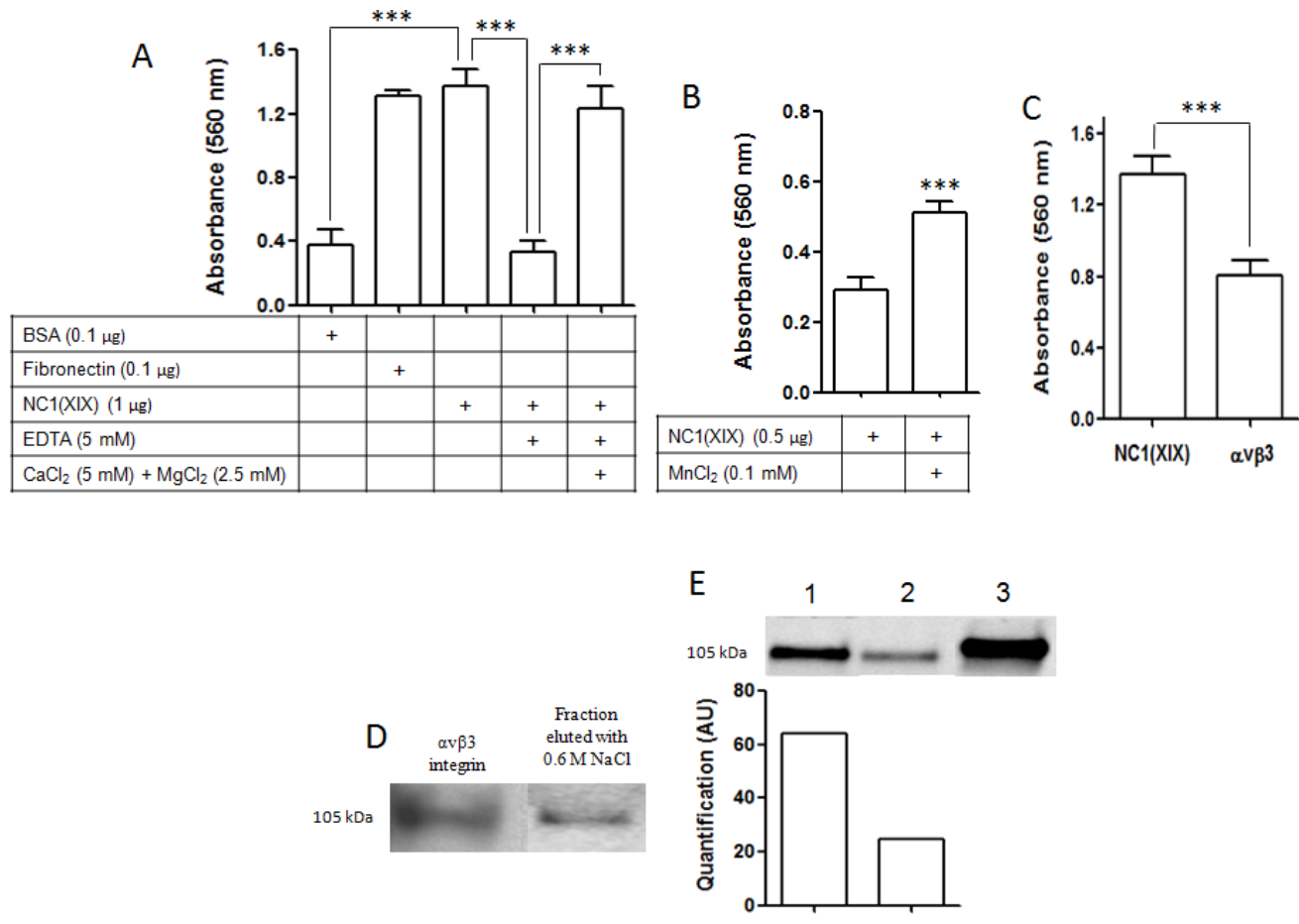

Figure 2: avß3 integrin specifically binds NC1(XIX). (A) Effect of divalent cations and EDTA on SK-MEL-28 cell adhesion. Cells were seeded in DMEM containing $5 \mathrm{mM} \mathrm{CaCl}_{2}+2.5 \mathrm{mM} \mathrm{MgCl}_{2}$ and/or $5 \mathrm{mM}$ EDTA, in wells coated with $0.1 \mu \mathrm{g}$ BSA used as negative control, $0.1 \mu \mathrm{g}$ fibronectin used as positive control or $1 \mu \mathrm{g}$ of $\mathrm{NC1}$ (XIX) for $2 \mathrm{~h}$ at $37^{\circ} \mathrm{C}$. (B) Effect of Mn ${ }^{2+}$ on SK-MEL-28 cell adhesion. Cells were seeded in HEPES buffer containing $0.1 \mathrm{mM} \mathrm{Mn}^{2+}$ in well coated with $1 \mu \mathrm{g}$ of $\mathrm{NC} 1$ (XIX) for $2 \mathrm{~h}$ at $37^{\circ} \mathrm{C}$. (C) Effect of $\alpha v \beta 3$ antibody on SK-MEL-28 cell adhesion. Cells were preincubated in DMEM containing $20 \mu \mathrm{g} / \mathrm{mL}$ of $\alpha v \beta 3$ antibody for 30 min at $37^{\circ} \mathrm{C}$ and then incubated in wells coated with $1 \mu \mathrm{g}$ of $\mathrm{NC} 1$ (XIX) for $2 \mathrm{~h}$ at $37^{\circ} \mathrm{C}$. After washing, cells were fixed with glutaraldehyde and stained with crystal violet. Absorbance was read at $560 \mathrm{~nm}$. The values are the means \pm SD of 4 replicates. *Significantly different from control $(* * * p<0.001)$. (D) SK-MEL-28 extracts were submitted by affinity chromatography on a NC1(XIX) peptide-bounded column. Bound proteins were eluted with increasing concentrations of $\mathrm{NaCl}(0.15,0.6$ and $1 \mathrm{M})$ and eluted samples were then analyzed by SDS-PAGE and western blot. The $0.6 \mathrm{M}$ eluted sample revealed a band which matched the $105 \mathrm{kDa}$ band of the denaturated recombinant $\alpha \mathrm{v} \beta 3 \mathrm{integrin}$ used as positive control. (E) In the liquid phase binding assay, recombinant $\alpha v \beta 3$ integrin was incubated with NC1(XIX) biotinylated peptide with or without an excess of $\mathrm{NC1}$ (XIX) (lane 1 and 2 respectively). Integrin-peptide complexes were precipitated using sepharose streptavidin beads and revealed by western blot analysis. Recombinant $\alpha \mathrm{v} \beta 3$ integrin was used a positive control (lane 3). 


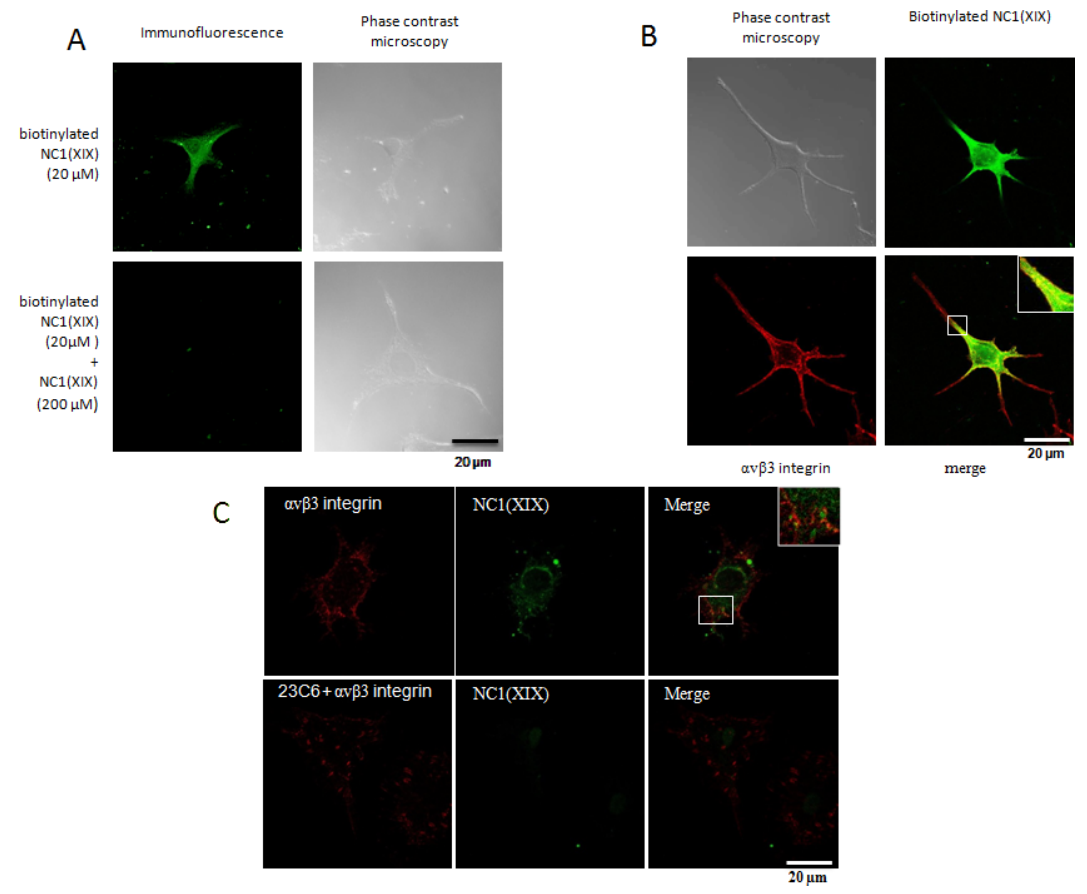

Figure 3: NC1(XIX) colocalizes with the avß3 integrin in SK-MEL-28 melanoma cells. (A) Fluorescent microscopy visualization of biotinylated $\mathrm{NC1}(\mathrm{XIX})$ on the cell surface of SK-MEL-28 melanoma cells (top panel). Competition between NC1(XIX) and biotinylated NC1(XIX) (low panel). (B) Fluorescent microscopy visualization of biotinylated NC1(XIX) (green) and $\alpha v \beta 3$ integrin (red). Yellow staining corresponds to areas where biotinylated $\mathrm{NC1}(\mathrm{XIX})$ and anti- $\alpha \mathrm{v} \beta 3$ integrin colocalize. Cells were cultured on glass slides, fixed with paraformaldehyde and labeled with biotinylated NC1(XIX) peptide and anti- $\alpha \mathrm{v} \beta 3$ integrin antibody. Scale bar: $20 \mu \mathrm{m}$. (C) SK-MEL-28 melanoma cells were cultured on glass slides, fixed with paraformaldehyde and incubated with biotinylated NC1(XIX) peptide and anti- $\alpha \mathrm{v} \beta 3$ integrin antibody (23C6).
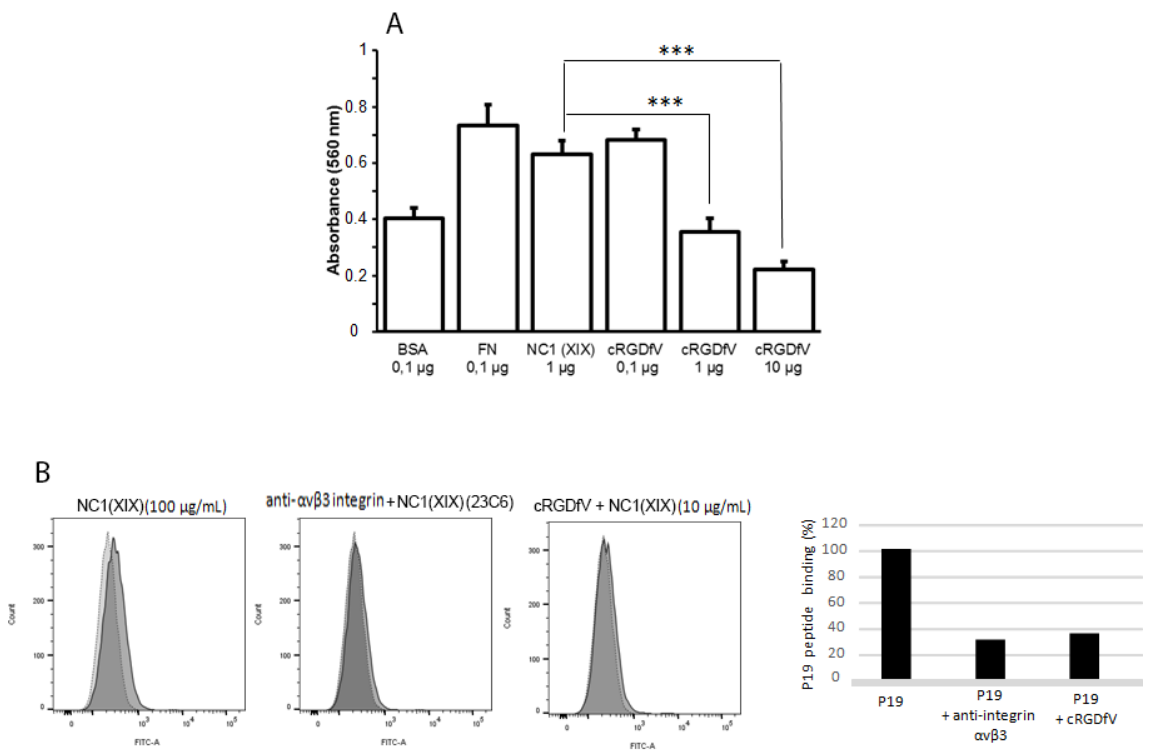

Figure 4: cRGDfV blocking peptide inhibits the NC1(XIX) binding on $\alpha$ v及3 integrin. (A) Effect of cRGDfV blocking peptide on SK-MEL-28 cell adhesion. Cells were preincubated in DMEM containing $0.1,1$ or $10 \mu \mathrm{g} / \mathrm{mL}$ of cRGDfV blocking peptide for 30 min at $37^{\circ} \mathrm{C}$ and then incubated in wells coated with $1 \mu \mathrm{g}$ of $\mathrm{NC} 1$ (XIX) for $2 \mathrm{~h}$ at $37^{\circ} \mathrm{C}$. After washing, cells were fixed with glutaraldehyde and stained with crystal violet. Absorbance was read at $560 \mathrm{~nm}$. The values are the means \pm SD of 4 replicates. *Significantly different from control $(* * * p<0.001)$. (B) Flow cytometry studies showed NC1(XIX) peptide $(100 \mu \mathrm{M})$ binding on SK-MEL-28 cell surface. (C) $\mathrm{NC1}(\mathrm{XIX})$ peptide $(100 \mu \mathrm{M})$ binding was inhibited by the addition of $\alpha \mathrm{v} \beta 3$ integrin antibody (LM609) or cRGDfV blocking peptide. 


\section{DISCUSSION}

Our previous studies demonstrated that the $\mathrm{NC1}$ domain of collagen XIX had anti-tumor effects by inhibiting migration and invasion of melanoma cells without affecting their proliferation $[15,16]$. We also showed that plasmin, a key enzyme in tumor invasion, generates a peptide derived from $\mathrm{NC1}$ (XIX) which reproduces the same inhibiting effects as the entire NC1(XIX) domain on the tumor cells in vitro and in vivo [9]. The aim of this study was to highlight the receptor(s) involved in the anti-tumor effect of NC1(XIX) and to elucidate the elicited signaling pathway.

Our present results demonstrated that the NC1(XIX) inhibits the migration of SK-MEL-28 cells. These results confirm previous studies from our laboratory demonstrating anti-tumor activity of $\mathrm{NC} 1$ (XIX) [15].
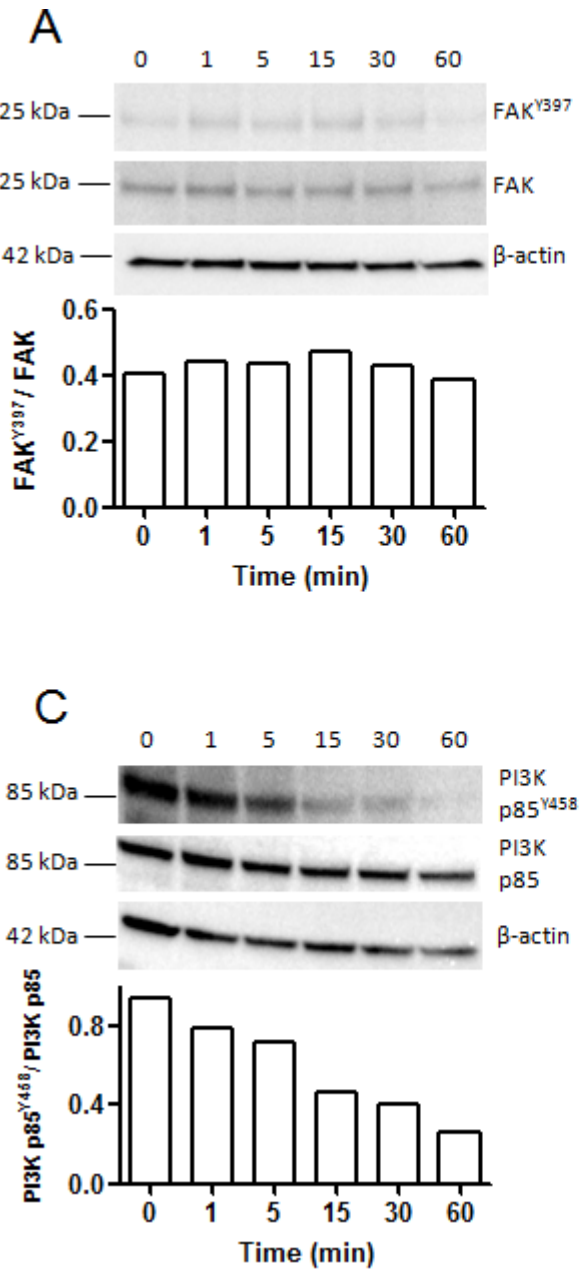

We showed that the adhesion of $\mathrm{NC1}(\mathrm{XIX})$ on SK-MEL-28 melanoma cells was calcium/magnesium/ manganese dependent, evoking the involvement of integrins. Integrins play key roles in malignant process as well in the early stages of tumor invasion as in the tumor angiogenesis or in the development of metastases [31]. We identified for the first time $\alpha v \beta 3$ integrin as a receptor for $\mathrm{NC1}$ (XIX) by affinity chromatography and liquid phase assay. This integrin is particularly involved in tumor genesis and was broadly described as one of the common receptor of the basement membrane collagens [32]. In confocal microscopy, we showed a co-localization of the integrin and NC1(XIX), showing proximity and interaction between these two molecules on melanoma cells. Furthermore, the zone of binding between the $\mathrm{NC1}$ (XIX) peptide and integrin $\alpha \mathrm{v} \beta 3$ is close to the integrin region of interaction with RGD peptide.
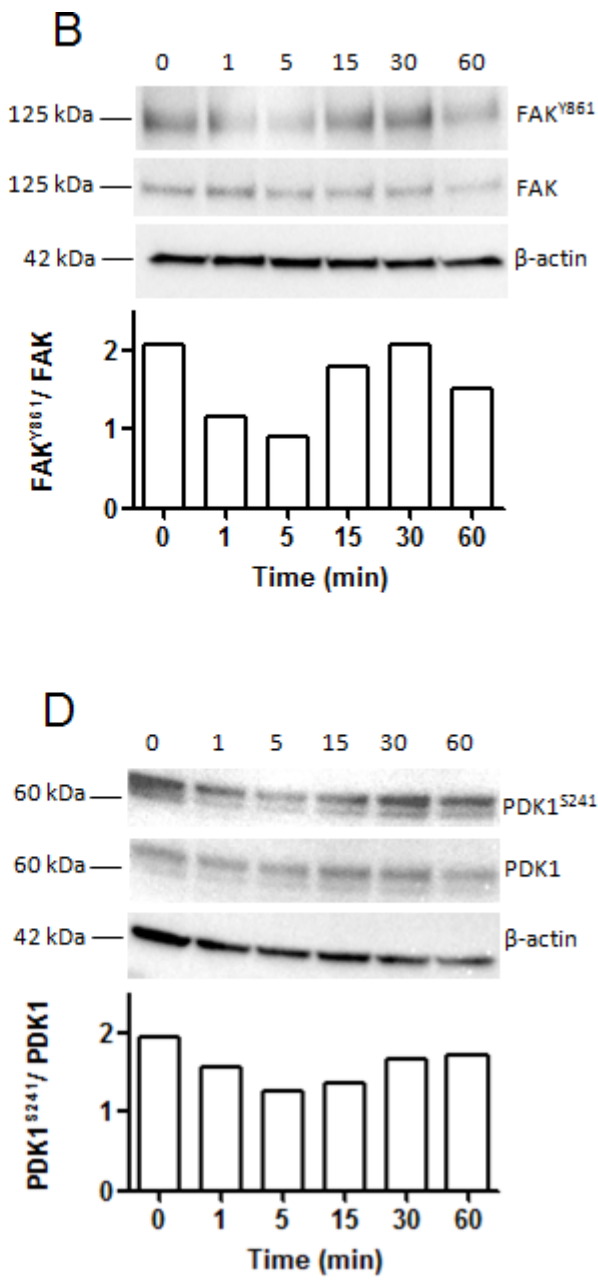

Figure 5: Kinetic analysis of FAK, PI3K p85 subunit of PI3 kinase and PDK1 phosphorylation in SK-MEL-28 melanoma cells after incubation with NC1(XIX). Western blot analysis of: (A) phosphorylated-FAK ${ }^{\mathrm{Y} 397}$, (B) phosphorylated$\mathrm{FAK}^{\mathrm{Y8} 61},(\mathbf{C})$ phosphorylated-PI3K p85 ${ }^{\mathrm{Y} 458}$ and (D) phosphorylated-PDK1 $1^{\mathrm{S241}}$ compared to total FAK, total PI3K p85 and total PDK1 expression respectively after incubation of SK-MEL-28 melanoma cells with $\mathrm{NC1}$ (XIX) for $0,1,5,15,30$ and 60 min. Bands were quantified by densitometric analysis. Phosphorylated protein was reported to corresponding total protein. 
A

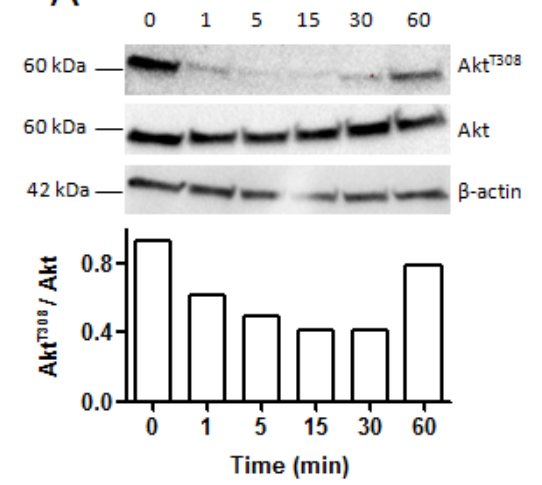

B
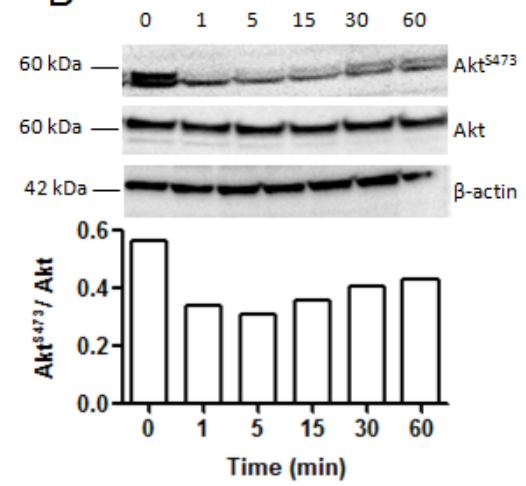

C
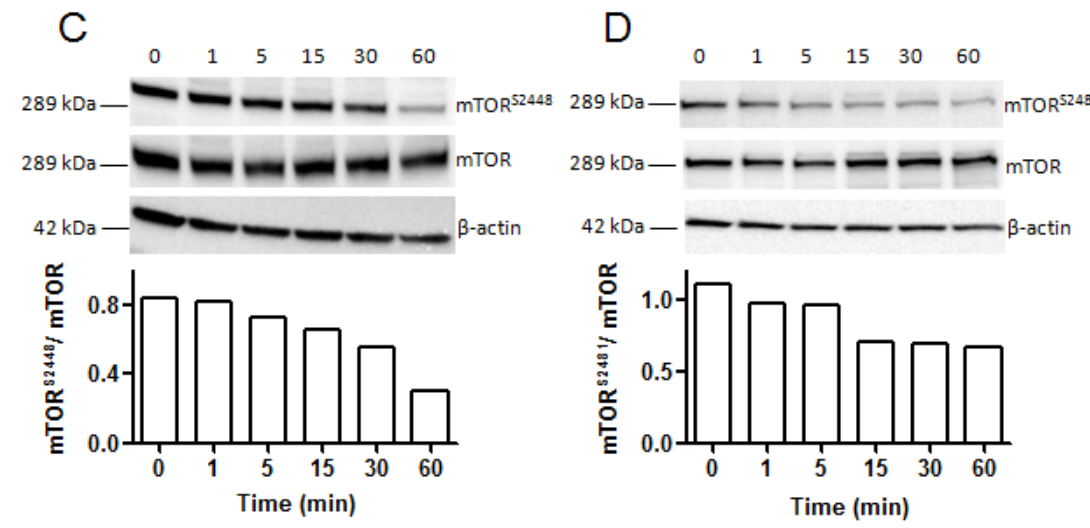

E

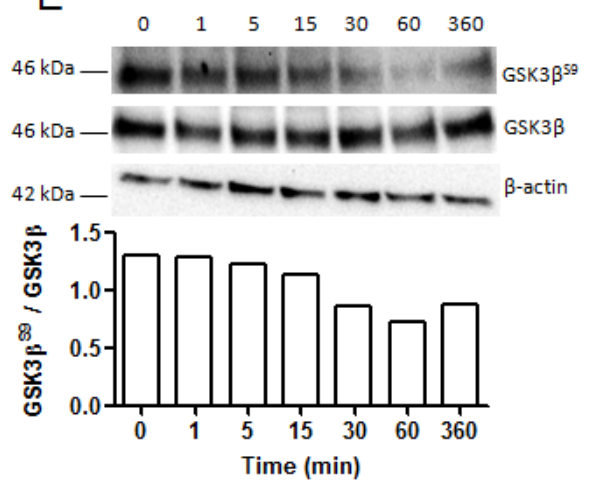

Figure 6: Kinetic analysis of Akt, mTOR and GSK3ß phosphorylation in SK-MEL-28 melanoma cells after incubation with NC1(XIX). Western blot analysis showing expression of: (A) phosphorylated-Akt ${ }^{\mathrm{T} 308}$, (B) phosphorylated-Akt ${ }^{\mathrm{S} 473}$, (C) phosphorylated-mTOR ${ }^{\mathrm{S} 2448}$, (D) phosphorylated-mTOR ${ }^{\mathrm{S} 2481}$ and (E) phosphorylated-GSK3$\beta^{\mathrm{S9}}$ compared to total Akt, total mTOR and total GSK3 $\beta$ expression, respectively, after incubation of SK-MEL-28 melanoma cells with NC1(XIX) for 0, 1, 5, 15, 30, 60 and 360 min. Bands were quantified by densitometric analysis. Phosphorylated protein was reported to corresponding total protein.

This was demonstrated by the competition found between the NC1(XIX) peptide and RGD peptide. Moreover, other receptors are probably involved since the inhibition observed was $50 \%$ only when blocking av $\beta 3$ integrin.

FAK is a multifunctional protein [33], especially involved in tumor invasion [29], angiogenesis [34] and energy metabolism of the tumor cell [35]. This is one of the molecules activated after ligand fixation [36]. Its activity is the result of a complex phosphorylation cascade leading to the activation of multiple proteins in the tumor process. Activation begins by auto-phosphorylation on tyrosine 397 following the integrin liganding [29]. Later on, the auto-phosphorylation allows the recruitment of Src protein which in turn phosphorylates FAK on many tyrosine residues (Tyr407, Tyr576, Tyr577, Tyr861, and Tyr925) [29, 37].

FAK $^{\mathrm{Y} 861}$ phosphorylation has been well studied in tumors and it is clear that this phosphorylation is essential for tumor cell migration [38]. We demonstrated that phosphorylation of $\mathrm{FAK}^{\mathrm{Y} 861}$ was inhibited by $\mathrm{NC1}$ (XIX) as soon as $1 \mathrm{~min}$ of incubation. Afterwards, this inhibition is the starter of a series of FAK partner phosphorylation inhibitions, which may explain the anti-tumor and antiangiogenic effects of $\mathrm{NC1}$ (XIX).

Two main signaling pathways, the RAS /RAF/MEK/ ERK pathway and the FAK/PI3K/Akt/mTOR pathway are activated in melanoma and may explain the progression of this cancer [39]. After activation of FAK via integrins, the $\mathrm{PI} 3 \mathrm{~K} / \mathrm{Akt} / \mathrm{mTOR}$ pathway is involved in the proliferation, migration, and angiogenesis of many cancers, including melanoma $[39,40]$.

Phosphorylation by the PI3K activating subunit is important, especially for the migration and growth of tumor cells $[41,42]$. Our results show that NC1(XIX) inhibits the phosphorylation of the regulatory subunit p85 of PI3K on tyrosine 458. Activated FAK was reported to phosphorylate the downstream PI3K that, in turn, activates Akt [43]. Akt is a central enzyme in tumor invasion, which participates in the regulation of all stages of tumor development [44]. Inhibition of PI3K and Akt promoted anoikis and decreased melanoma tumor growth by inhibiting the Rho subfamily [45]. PDK1 
(phosphoinositide-dependent kinase 1) and the complex mTORC2 activates Akt through threonine 308 and serine 473 phosphophylations, respectively [43, 46].

As mentioned above, these two Akt-activating protein kinases are also activated by phosphorylation, essential for their activity, on serine 241 for PDK1 [47] and on serine 2481 for mTORC2 [48].

We demonstrated that $\mathrm{NC1}$ (XIX) inhibited the phosphorylation of many partners $\left(\mathrm{Akt}^{\mathrm{S} 473}, \mathrm{Akt}^{\mathrm{T} 308}\right.$, PDK $\left.1^{\mathrm{S} 241}, \mathrm{mTORC} 2^{\mathrm{S} 2481}\right)$ of the signaling pathway. In addition, NC1(XIX) also induced an inhibition of phosphorylation of the second mTORC1 complex on Serine 2448. This phosphorylation is involved in tumor invasion, particularly in melanoma progression [49] and its phosphorylation is essential for its activity $[48,50]$.

Moreover, we demonstrated that NC1(XIX) induced an inhibition of GSK3 $\beta$ (Glycogen synthase kinase 3- $\beta$ ) by decreasing its phosphorylation degree. GSK3 $\beta$ plays an important role in the activity of mTOR complex [51]. It is a serine/threonine kinase initially described in the regulation of glycogen synthesis [52]. It also plays a significant role on directional cell migration [53] and is described as a therapeutic target in melanoma [54]. Unlike most kinases, GSK3 $\beta$ is activated under its dephosphorylated form. More recently, Koo et al. have shown that activation of GSK3 $\beta$ was essential for potentiating the action of antitumoral mTOR inhibitor [55]. The increase of GSK3 $\beta$ activity induced by $\mathrm{NC1}(\mathrm{XIX})$, through a GSK3 $\beta$ dephosphorylation process, could explain the effects of NC1(XIX) on mTOR inhibition and could also explain its anti-tumor effects on SK-MEL-28 and other melanoma cell lines previously described $[15,16]$.

GSK3 $\beta$ implication in the mechanism of action of NC1 (XIX) suggests the involvement of the Wnt / $\beta$-catenin signaling pathway. This pathway is frequently deregulated in carcinogenesis and is most often of poor prognosis, in particular in colon cancer [56]. However, its role in melanoma is still controversial and ambiguous. The Wnt / $\beta$-catenin pathway is sometimes pro-tumoral and sometimes anti-tumoral in other circumstances. According to the literature, it inhibits the proliferation and migration of tumor cells but increases their metastatic potential [57-58]. Given the complexity of this pathway and its role in melanoma, studying the effects of NC1 (XIX) on this pathway will be part of our prospects.

In summary, we have identified for the first time the $\alpha v \beta 3$ integrin as a receptor of the $\mathrm{NC} 1$ domain of the collagen XIX. We have demonstrated that NC1(XIX) controls the majority of the partners of the FAK/PI3K/Akt/mTOR pathway by inducing the inhibition of their phosphorylations, essential for their biological activity (Figure 7). Inhibition of several participants in a signaling pathway is more powerful than that of a single molecule [55]. Treatments targeting this central signaling pathway in the development of melanoma

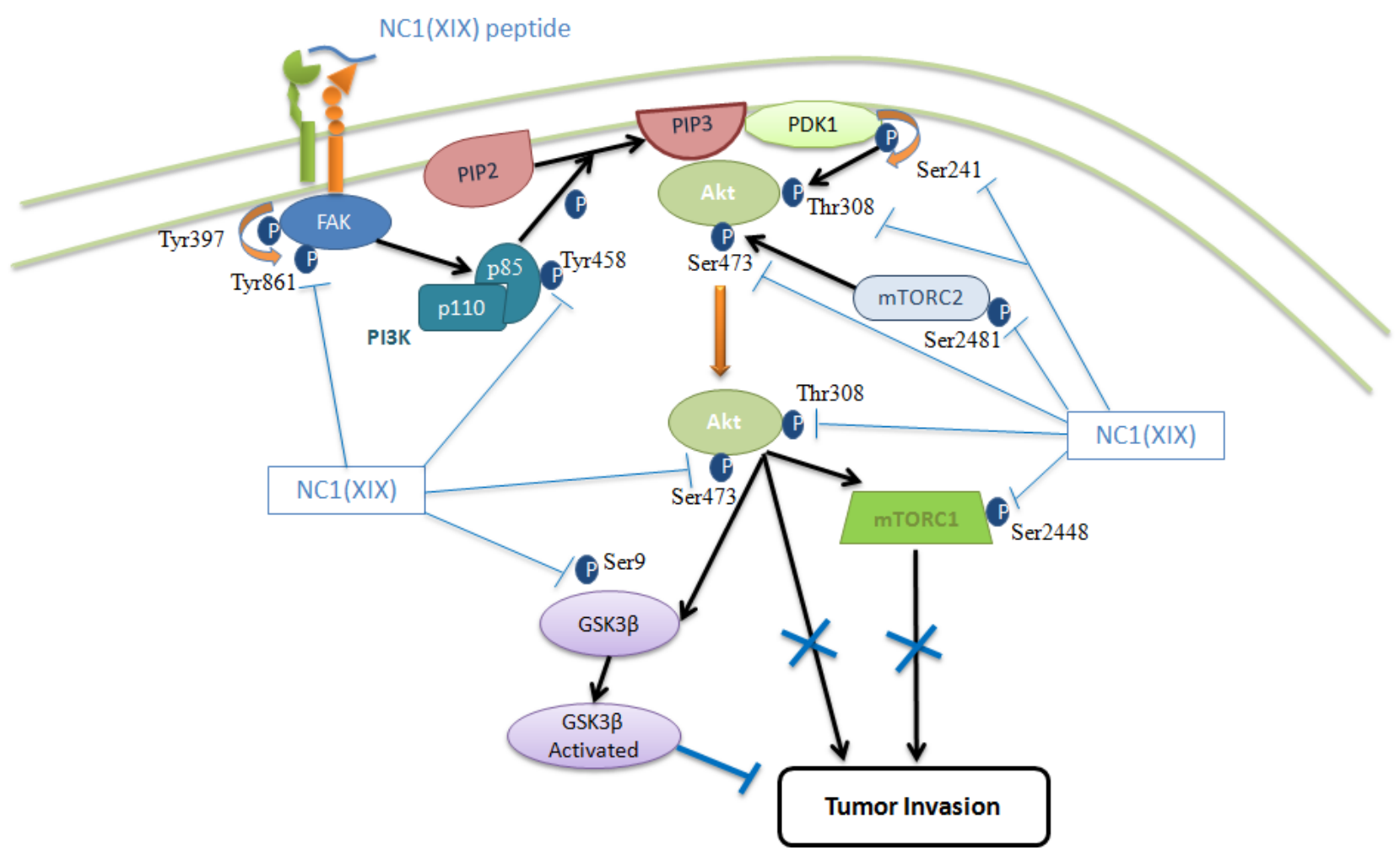

Figure 7: Schematic representation of the FAK / PI3K / Akt / mTOR pathway and modifications of phosphorylated proteins after incubation with NC1(XIX). 
are promising [30] and new molecules should be developed in this in this aim. $\mathrm{NC1}$ (XIX) seems to have the potentiality for the design of new anti-cancer drugs.

\section{MATERIALS AND METHODS}

\section{Peptides synthesis}

$\mathrm{NC1}$ (XIX) peptide was purchased from Proteogenix $^{\circledR}$ (Schiltigheim, France). It was obtained by solid-phase synthesis using a FMOC (N-(9-fluorenyl) methoxy-carbonyl) derivative procedure. It was then purified by reverse phase high performance liquid chromatography using a C18 column, eluted by a gradient of acetonitrile in trifluoroacetic acid, and finally lyophilized [59]. The NC1(XIX) peptide sequence was NPEDCLYPVSHAHQRTGGN. Biotinylated NC1(XIX) peptide was also purchased from Proteogenix ${ }^{\circledR}$ and had the following sequence NPEDCLYPVSHAHQRTGGNK-Biotin.

\section{Cell culture}

SK-MEL-28 melanoma cell line was purchased from the American Type Culture Collection (ATCC, Manassas, VA). Cell were grown in Dulbecco's Modified Eagle's medium (DMEM) supplemented with 10\% Fetal Bovine Serum (FBS) in Nunclon ${ }^{\circledR} 25 \mathrm{~cm}^{2}, 75 \mathrm{~cm}^{2}$ or $150 \mathrm{~cm}^{2}$ flasks (Dutscher Brumath, France) at $37^{\circ} \mathrm{C}$ in a humid atmosphere $\left(5 \% \mathrm{CO}_{2}, 95 \%\right.$ air). All culture media and reagents were purchased from Life Technologies (Invitrogen, Strasbourg, France).

\section{Adhesion assay}

For cell adhesion assays, 96-well microtiter plates were purchased from Dutscher (Brumath, France). Plates were coated with the different substrates described below, diluted in carbonate buffer $(0.2 \mathrm{M}$ sodium carbonate, $0.2 \mathrm{M}$ sodium bicarbonate, $\mathrm{pH} 9.6)$ overnight at $4^{\circ} \mathrm{C}$. Bovine serum albumin (BSA) (Euromedex, Souffelweyersheim, France) at $0.1 \mu \mathrm{g} / \mathrm{well}$ was used as negative control whereas fibronectin (Millipore, Molsheim, France) at $0.1 \mu \mathrm{g} /$ well was used as positive control. NC1(XIX) was coated in the same carbonate buffer at $1 \mu \mathrm{g} / \mathrm{well}$. Cells were detached with a Versene buffer $(126 \mathrm{mM}$ $\mathrm{NaCl}, 5 \mathrm{mM} \mathrm{KCl}, 1 \mathrm{mM}$ EDTA, $50 \mathrm{mM}$ HEPES) and centrifuged at $800 \mathrm{~g}$ for $5 \mathrm{~min}$ at room temperature. Cells were then incubated with $2 \mathrm{mM} \mathrm{CaCl}_{2}$ and $0.5 \mathrm{mM} \mathrm{MgCl}_{2}$ in DMEM. After counting, cells were seeded at a density of 60,000 cells in $100 \mu \mathrm{L} /$ well and incubated for $2 \mathrm{~h}$ at $37^{\circ} \mathrm{C}$ in $5 \% \mathrm{CO}_{2}$. Unattached cells were removed by washing with PBS. Attached cells were fixed with $1.1 \%$ glutaraldehyde in PBS for 20 min. After washing, cells were stained with $0.1 \%$ crystal violet for $20 \mathrm{~min}$. After extensive washing with distilled water and air-drying, crystal violet was eluted in $100 \mu \mathrm{L} /$ well of $10 \%$ acetic acid. Absorbance was then measured at $560 \mathrm{~nm}$. To investigate the effect of divalent cations or EDTA on adhesion, cells were incubated for 2 hours at $37^{\circ} \mathrm{C}$ in $5 \% \mathrm{CO}_{2}$ with or without $5 \mathrm{mM}$ EDTA and/or $5 \mathrm{mM} \mathrm{CaCl}_{2}$ and $2.5 \mathrm{mM}$ $\mathrm{MgCl}_{2}$ or $0.1 \mathrm{mM} \mathrm{Mn}^{2+}$. For $\mathrm{MnCl}_{2}$ adhesion assay, cells were centrifuged at $800 \mathrm{~g}$ for $5 \mathrm{~min}$ at room temperature and then incubated in HEPES buffer $(150 \mathrm{mM} \mathrm{NaCl}, 50$ $\mathrm{mM}$ HEPES). For adhesion blocking assay, cells were preincubated with $20 \mu \mathrm{g} / \mathrm{mL}$ of anti- $\alpha v \beta_{3}$ integrin antibody (sc7312 from Santa Cruz Biotechnology, USA) diluted in $2 \mathrm{mM} \mathrm{CaCl}_{2}$ and $0.5 \mathrm{mM} \mathrm{MgCl}$, supplemented DMEM for $30 \mathrm{~min}$ on a carrousel at $37^{\circ} \mathrm{C}$ before adhesion assay. In complementary experiments, cells were incubated with 0.1 to $10 \mu \mathrm{g}$ of cRGDfV (Calbiochem ${ }^{\mathrm{TM}}$ ) (blocking $\alpha v \beta_{3}$ integrin peptide).

\section{Scratch wound assay}

SK-MEL-28 cells were seeded in 12-well plates and cultivated to confluence in DMEM supplemented with $10 \% \mathrm{FBS}$ at $37^{\circ} \mathrm{C}$ in $5 \% \mathrm{CO}_{2}$. At confluence, cells were incubated with fresh DMEM without FBS overnight at $37^{\circ} \mathrm{C}$. A homogenous wound was then created in each well with a sterile $200 \mu \mathrm{L}$ pipet tip. After washing with DMEM, cells were incubated in DMEM with or without $20 \mu \mathrm{M} \mathrm{NC1}$ (XIX) for 24,48 or $72 \mathrm{~h}$ at $37^{\circ} \mathrm{C}$. Wounds were microphotographed at $0,24,48$ or $72 \mathrm{~h}$ of incubation and wound closure was measured.

\section{Immunocytofluorescence assay}

30,000 SK-MEL-28 melanoma cells were seeded on coverslip placed into 24-well culture plate and then incubated for $24 \mathrm{~h}$ in DMEM supplemented with $10 \%$ FBS at $37^{\circ} \mathrm{C}$ in $5 \% \mathrm{CO}_{2}$. Cells were fixed with $4 \%$ paraformaldehyde in PBS (w/v) and incubated for $10 \mathrm{~min}$ at room temperature. After washing with PBS, cells were then incubated with biotinylated NC1(XIX), NC1(XIX) and/or anti- $\alpha v \beta 3$ integrin antibody (MAB1976 Millipore, Molsheim, France) diluted 1/200 in 1\% BSA-supplemented PBS for $1 \mathrm{~h}$ at room temperature. After washing with PBS, cells were incubated respectively with a $1 / 1000$ diluted Alexa fluor 488- or 568-conjugated secondary antibody (A11057 and A11004 respectively, Invitrogen, Carlsbad, USA) in PBS supplemented with $1 \%$ BSA for $30 \mathrm{~min}$ in a dark chamber at room temperature. Coverslips were then mounted with aqueous mounting medium (Thermo Scientific, Villebon sur Yvette, France) and examined using a confocal laser scanning microscope (Zeiss LSH710, Carl Zeiss MicroImaging, GmbH, Germany).

\section{Affinity chromatography}

SK-MEL-28 protein extracts were chromatographed at $4^{\circ} \mathrm{C}$ on a HiTrap NHS-activated Sepharose High 
Performance column (GE Healthcare, Orsay, France) previously functionalized with $\mathrm{NC1}(\mathrm{XIX})$ peptide, according to the manufacturer instructions. Unbound material was removed with $30 \mathrm{~mL}$ of washing buffer (10 mM Tris, $1 \mathrm{mM} \mathrm{CaCl}, 1 \mathrm{mM} \mathrm{MgCl}$, pH 7.6, 1/100 PIC (ProteoBlock Protease Inhibitor Cocktail, Fermentas, Illkirch, France) (w/v) and $0.1 \%$ octylglucoside). Proteins bound to the affinity column were then eluted with elution buffer (10 mM Tris, $\mathrm{pH} 7.6,1 / 100 \mathrm{PIC}(\mathrm{w} / \mathrm{v})$ and $0.1 \%$ octylglucoside) supplemented with increasing concentrations of $\mathrm{NaCl}(0.15,0.6$ and $1 \mathrm{M})$. Eluted samples were then solubilized in SDS sample buffer with $10 \mathrm{mM}$ DTT, denatured at $95^{\circ} \mathrm{C}$ for $5 \mathrm{~min}$ and submitted to western blotting using an $\beta 3$ integrin antibody (Santa Cruz Biotechnology, Heidelberg, Germany.

\section{Flow cytometry}

Anti-integrin primary antibody and secondary anti-mouse or anti-rabbit antibody were used according to manufacturer's instruction (Supplementary Table 1). Cells were analysed by LSRFortessa flow cytometer (BD Biosciences) using a laser emitting at $488 \mathrm{~nm}$ and detecting Alexa Fluor 488 emission with a 530/30 bandpass filter. Ten thousand cells, gated on forward scatter vs. side scatter, were collected for each sample. Quantification of integrin expression was performed by median fluorescence intensity (MFI) ratio of sample / control. MFI ratio of 2 were used as the threshold for positivity. Results were analyzed using software Flow Jo (TreeStar, Inc; SA).

\section{Integrin binding assay}

One $\mu \mathrm{g}$ of recombinant $\alpha v \beta 3$ integrin (3050-AV-0505 R\&D Systems) was combined with $1 \mu \mathrm{g}$ of biotinylated NC1(XIX) peptide in $500 \mu \mathrm{L}$ of Dulbecco's PBS without divalent cations $\left(\mathrm{Ca}^{2+}\right.$ or $\left.\mathrm{Mg}^{2+}\right)$. This mixture was incubated with or without $7 \mu \mathrm{g}$ of unbiotinylated $\mathrm{NC1}$ (XIX) peptide with gentle shaking at $4^{\circ} \mathrm{C}$ for $30 \mathrm{~min} .10 \mu \mathrm{L}$ of streptavidin sepharose beads (Cell Signaling Technology) were added to the samples for a second incubation period of $30 \mathrm{~min}$ at $4^{\circ} \mathrm{C}$. Samples were washed twice with $1 \mathrm{~mL}$ PBS and centrifuged at $500 \mathrm{~g}$ for $5 \mathrm{~min}$ at room temperature. $20 \mu \mathrm{L}$ of loading buffer (500 mM tris, 10\% SDS (w/v), $20 \%$ saccharose (w/v), pH 6.8, $75 \mathrm{mg}$ bromophenol blue, $5 \%$ 2-mercaptoethanol (v/v)) were added to each pellet.
Samples were denatured at $95^{\circ} \mathrm{C}$ for $5 \mathrm{~min}$, centrifuged and supernatants were submitted to SDS-PAGE.

\section{Western blotting}

SK-MEL-28 melanoma cells were cultured as previously described in Nunclon $25 \mathrm{~cm}^{2}$ flasks. At $50 \%$-confluence, cells were washed with PBS and incubated with DMEM without FBS overnight at $37^{\circ} \mathrm{C}$. Cells were then treated with $50 \mu \mathrm{M}$ NC1(XIX) diluted in DMEM without FBS for 0 , 1, 5, 15, 30 or $60 \mathrm{~min}$. All flasks were frozen at $-80^{\circ} \mathrm{C}$ until protein extraction. Cells were scrapped with $200 \mu \mathrm{L}$ of protein lysis buffer (RIPA buffer, Sigma, St Quentin Fallavier, France), supplemented with $1 \%$ PIC, $2 \mathrm{mM}$ sodium orthovanadate and $50 \mathrm{mM}$ $\mathrm{NaF}$ (Sigma, St Quentin Fallavier, France) and cell lysate were incubated for $30 \mathrm{~min}$ at $4^{\circ} \mathrm{C}$. Cellular debris was pelleted by centrifugation of lysates at $10000 \mathrm{~g}$ for $10 \mathrm{~min}$ at $4^{\circ} \mathrm{C}$. Protein concentration of the supernatant was quantified using Biorad Protein Assay (BioRad, MarnesLa-Coquette, France) according to the manufacturer's instructions.

For western blot analysis, samples were reduced by $10 \mathrm{mM}$ dithiothreitol and denaturated $5 \mathrm{~min}$ at $95^{\circ} \mathrm{C}$. Samples were submitted to SDS-PAGE (Criterion gel, BioRad, Marnes-La-Coquette, France) $(20 \mu \mathrm{g}$ of total protein per lane) and then transferred onto membrane using Transblot Turbo (BioRad, Marnes-La-Coquette, France). Membranes were blocked with 5\% BSA in TBS-T $(0.1 \%$ Tween $20,50 \mathrm{mM}$ Tris $\mathrm{HCl}$ buffer, $150 \mathrm{mM} \mathrm{NaCl}, \mathrm{pH} 7.5$ ) for $2 \mathrm{~h}$ at room temperature. All antibodies were incubated in TBS-T supplemented with $1 \%$ BSA overnight at $4^{\circ} \mathrm{C}$. Antibody references and dilutions are summarized in Table 1. After washing with TBS-T, membranes were incubated with $1 / 10000$ diluted corresponding peroxidase-conjugated second antibody diluted in TBS-T, 1\% BSA for $1 \mathrm{~h}$ at room temperature. After washing, immune complexes were revealed using ECL prime chemiluminescence detection kit (GE Healthcare, Orsay, France) according to the manufacturer's instructions.

\section{Statistical analysis}

Results were expressed as means +/- standard deviation or SEM. Statistical significance between groups was assessed by unpaired Student's $t$ test. 
Table 1: Antibody list and dilution used

\begin{tabular}{|c|c|c|c|}
\hline Antibody & Manufacturer & Reference & Dilution \\
\hline Phospho-FAK ${ }^{\text {Tyr } 458}$ & Novex by life Technology ${ }^{\mathrm{TM}}$ & $44626 \mathrm{G}$ & $1 / 1000$ \\
\hline Phospho-FAK ${ }^{\mathrm{Ty} r 397}$ (D20B1) & Cell Signaling Technology ${ }^{\circledR}$ & 8556 & $1 / 1000$ \\
\hline FAK & Cell Signaling Technology ${ }^{\circledR}$ & 3285 & $1 / 1000$ \\
\hline phospho-P13Kp85 $5^{\text {Tyr458 }}$ & Cell Signaling Technology ${ }^{\circledR}$ & 4228 & $1 / 1000$ \\
\hline P13Kp85 & Millipore $^{\mathrm{TM}}$ & $06-195$ & $1 / 1000$ \\
\hline phospho-PDK1 ${ }^{\text {Ser 241 }}(\mathrm{C} 49 \mathrm{H} 2)$ & Cell Signaling Technology ${ }^{\circledR}$ & 3438 & $1 / 1000$ \\
\hline PDKI (D37A7) & Cell Signaling Technology ${ }^{\circledR}$ & 5662 & $1 / 1000$ \\
\hline phospho-AKT ${ }^{\text {Ser473 }}$ (D9E) & Cell Signaling Technology ${ }^{\circledR}$ & 4060 & $1 / 1000$ \\
\hline phospho-AKT $^{\text {Thr } 308}$ (C31E5E) & Cell Signaling Technology ${ }^{\circledR}$ & 2965 & $1 / 1000$ \\
\hline AKT & Cell Signaling Technology ${ }^{\circledR}$ & 9272 & $1 / 1000$ \\
\hline phospho-mTOR $^{\text {Ser } 2448}$ & Cell Signaling Technology ${ }^{\circledR}$ & 2971 & $1 / 1000$ \\
\hline phospho-mTOR Ser 2481 & Cell Signaling Technology ${ }^{\circledR}$ & 2974 & $1 / 1000$ \\
\hline mTOR (L27D4) & Cell Signaling Technology ${ }^{\circledR}$ & 4517 & $1 / 1000$ \\
\hline phospho-GSK3 $3 \beta^{\text {Ser } 9}$ & Cell Signaling Technology ${ }^{\circledR}$ & 9323 & $1 / 2000$ \\
\hline GSK3 $\beta$ & Cell Signaling Technology ${ }^{\circledR}$ & 9325 & $1 / 2000$ \\
\hline
\end{tabular}

\section{ACKNOWLEDGMENTS AND FUNDINGS}

This work was supported by grants from the "Université de Reims-Champagne-Ardenne », the "Centre National de la Recherche Scientifique », the " Ligue Nationale contre le Cancer ", the "Region Champagne-Ardenne » and the "Fonds Européen de Développement Régional (FEDER)».

The authors thank the PICT (Cell and Tissue Imaging platform) and the Flow Cytometry Core URCACyt of the University of Reims ChampagneArdenne (France) for providing time and support.

\section{Author contributions}

LR, SBP, JBO, JCM and FXM designed the study, analysed the results and contributed to the writing of the manuscript. CS and ADD performed High Pressure Liquid Chromatography and western blots. BB performed the immunofluorescence studies. AV and MD performed scratch wound assays and western blots.

\section{CONFLICTS OF INTEREST}

The authors declare that they have no conflicts of interest.

\section{REFERENCES}

1. Yoshioka H, Zhang H, Ramirez F, Mattei M-G, MoradiAmeli M, van der Rest M, Gordon MK. Synteny between the loci for a novel FACIT-like collagen locus (D6S228E) and $\alpha 1$ (IX) collagen (COL9A1) on 6q12-q14 in humans. Genomics. 1992; 13:884-886.
2. Inoguchi $\mathrm{K}$, Yoshioka $\mathrm{H}$, Khaleduzzaman M, Ninomiya Y. The mRNA for \&alpha;1(XIX) Collagen Chain, a New Member of FACITs, Contains a Long Unusual 3' Untranslated Region and Displays Many Unique Splicing Variants. J Biochem. 1995; 117:137-146.

3. Khaleduzzaman M, Sumiyoshi H, Ueki Y, Inoguchi K, Ninomiya Y, Yoshioka H. Structure of the human type XIX collagen (COL19A1) gene, which suggests it has arisen from an ancestor gene of the FACIT family. Genomics. 1997; 45:304-312.

4. Myers JC, Sun MJ, D'Ippolito JA, Jabs EW, Neilson EG, Dion AS. Human cDNA clones transcribed from an unusually high-molecular-weight RNA encode a new collagen chain. Gene. 1993; 123:211-217.

5. Myers JC, Yang H, D'Ippolito JA, Presente A, Miller MK, Dion AS. The triple-helical region of human type XIX collagen consists of multiple collagenous subdomains and exhibits limited sequence homology to alpha 1(XVI). J Biol Chem. 1994; 269:18549-18557.

6. Gerecke DR, Olson PF, Koch M, Knoll JH, Taylor R, Hudson DL, Champliaud MF, Olsen BR, Burgeson RE. Complete primary structure of two splice variants of collagen XII, and assignment of alpha 1(XII) collagen (COL12A1), alpha 1(IX) collagen (COL9A1), and alpha 1(XIX) collagen (COL19A1) to human chromosome 6q12-q13. Genomics. 1997; 41:236-242.

7. Myers JC, Li D, Bageris A, Abraham V, Dion AS, Amenta PS. Biochemical and immunohistochemical characterization of human type XIX defines a novel class of basement membrane zone collagens. Am J Pathol. 1997; 151:1729-1740.

8. Myers JC, Li D, Amenta PS, Clark CC, Nagaswami C, Weisel JW. Type XIX collagen purified from human 
umbilical cord is characterized by multiple sharp kinks delineating collagenous subdomains and by intermolecular aggregates via globular, disulfide-linked, and heparin-binding amino termini. J Biol Chem. 2003; 278:32047-32057.

9. Oudart J-B, Brassart-Pasco S, Vautrin A, Sellier C, Machado C, Dupont-Deshorgue A, Brassart B, Baud S, Dauchez M, Monboisse J-C, Harakat D, Maquart F-X, Ramont L. Plasmin releases the anti-tumor peptide from the NC1 domain of collagen XIX. Oncotarget. 2015; 6: 3656-3668. doi: 10.18632/oncotarget.2849.

10. Sumiyoshi H, Inoguchi K, Khaleduzzaman M, Ninomiya $Y$, Yoshioka H. Ubiquitous Expression of the $\alpha 1$ (XIX) Collagen Gene (Col19a1) during Mouse Embryogenesis Becomes Restricted to a Few Tissues in the Adult Organism. J Biol Chem. 1997; 272:17104-17111.

11. Amenta PS, Hadad S, Lee MT, Barnard N, Li D, Myers JC. Loss of types XV and XIX collagen precedes basement membrane invasion in ductal carcinoma of the female breast. J Pathol. 2003;199:298-308.

12. Myers JC, Li D, Rubinstein NA, Clark CC. Up-regulation of type XIX collagen in rhabdomyosarcoma cells accompanies myogenic differentiation. Exp Cell Res. 1999; 253:587-598.

13. Sumiyoshi H, Mor N, Lee SY, Doty S, Henderson S, Tanaka S, Yoshioka H, Rattan S, Ramirez F. Esophageal muscle physiology and morphogenesis require assembly of a collagen XIX-rich basement membrane zone. J Cell Biol. 2004; 166:591-600.

14. Su J, Gorse K, Ramirez F, Fox MA. Collagen XIX Is Expressed by Interneurons and Contributes to the Formation of Hippocampal Synapses. J Comp Neurol. 2010; 518:229-253.

15. Ramont L, Brassart-Pasco S, Thevenard J, Deshorgue A, Venteo L, Laronze JY, Pluot M, Monboisse J-C, Maquart F-X. The NC1 domain of type XIX collagen inhibits in vivo melanoma growth. Mol Cancer Ther. 2007; 6:506-514.

16. Toubal A, Ramont L, Terryn C, Brassart-Pasco S, Patigny D, Sapi J, Monboisse J-C, Maquart F-X. The NC1 domain of type XIX collagen inhibits melanoma cell migration. Eur J Dermatol. 2010; 20:712-718.

17. Barczyk M, Carracedo S, Gullberg D. Integrins. Cell Tissue Res. 2010; 339:269-280.

18. Pasco S, Monboisse J-C, Kieffer N. The $\alpha 3$ (IV)185-206 Peptide from Noncollagenous Domain 1 of Type IV Collagen Interacts with a Novel Binding Site on the $\beta 3$ Subunit of Integrin $\alpha v \beta 3$ and Stimulates Focal Adhesion Kinase and Phosphatidylinositol 3-Kinase Phosphorylation. J Biol Chem. 2000; 275:32999-33007.

19. Maeshima Y, Yerramalla UL, Dhanabal M, Holthaus KA, Barbashov S, Kharbanda S, Reimer C, Manfredi M, Dickerson WM, Kalluri R. Extracellular Matrix-derived Peptide Binds to $\alpha v \beta 3$ Integrin and Inhibits Angiogenesis. J Biol Chem. 2001; 276:31959-31968.

20. Pedchenko V, Zent R, Hudson BG. $\alpha v \beta 3$ and $\alpha v \beta 5$ Integrins Bind Both the Proximal RGD Site and Non-RGD Motifs within Noncollagenous (NC1) Domain of the $\alpha 3$ Chain of Type IV Collagen: implication for the mechanism of endothelia cell adhesion. J Biol Chem. 2004; 279:2772-2780.

21. Sudhakar A, Nyberg P, Keshamouni VG, Mannam AP, Li J, Sugimoto H, Cosgrove D, Kalluri R. Human $\alpha 1$ type IV collagen $\mathrm{NC} 1$ domain exhibits distinct antiangiogenic activity mediated by $\alpha 1 \beta 1$ integrin. J Clin Invest. 2005; 115:2801-2810.

22. Magnon C, Galaup A, Mullan B, Rouffiac V, Bidart J-M, Griscelli F, Opolon P, Perricaudet M. Canstatin Acts on Endothelial and Tumor Cells via Mitochondrial Damage Initiated through Interaction with $\alpha v \beta 3$ and $\alpha v \beta 5$ Integrins. Cancer Res. 2005; 65:4353-4361.

23. Brassart-Pasco S, Sénéchal K, Thevenard J, Ramont L, Devy J, Di Stefano L, Dupont-Deshorgue A, Brézillon S, Feru J, Jazeron J-F, Diebold M-D, Ricard-Blum S, Maquart F-X, et al. Tetrastatin, the NC1 Domain of the a4(IV) Collagen Chain: A Novel Potent Anti-Tumor Matrikine. PLoS One 2012; 7:e29587. doi: 10.1371/journal. pone.0029587.

24. Rehn M, Veikkola T, Kukk-Valdre E, Nakamura H, Ilmonen M, Lombardo CR, Pihlajaniemi T, Alitalo K, Vuori K. Interaction of endostatin with integrins implicated in angiogenesis. Proc Natl Acad Sci U S A. 2001; 98:1024-1029.

25. Su J, Stenbjorn RS, Gorse K, Su K, Hauser KF, Ricard-Blum S, Pihlajaniemi T, Fox MA. Target-Derived Matricryptins Organize Cerebellar Synapse Formation Through $\alpha 3 \beta 1$ Integrins. Cell Rep. 2012; 2:223-230.

26. Faye C, Moreau C, Chautard E, Jetne R, Fukai N, Ruggiero F, Humphries MJ, Olsen BR, Ricard-Blum S. Molecular Interplay between Endostatin, Integrins, and Heparan Sulfate. J Biol Chem. 2009; 284:22029-22040.

27. Uzdensky AB, Demyanenko SV, Bibov MY. Signal transduction in human cutaneous melanoma and target drugs. Curr Cancer Drug Targets. 2013; 13:843-866.

28. Lee BY, Timpson P, Horvath LG, Daly RJ. FAK signaling in human cancer as a target for therapeutics. Pharmacol Ther. 2015; 146:132-149.

29. Sulzmaier FJ, Jean C, Schlaepfer DD. FAK in cancer: mechanistic findings and clinical applications. Nat Rev Cancer. 2014; 14:598-610.

30. Jazirehi AR, Wenn PB, Damavand M. Therapeutic implications of targeting the PI3Kinase/AKT/mTOR signaling module in melanoma therapy. Am J Cancer Res. 2012; 2:178-191.

31. Contois L, Akalu A, Brooks PC. Integrins as "functional hubs" in the regulation of pathological angiogenesis. Semin Cancer Biol. 2009; 19:318-328.

32. Monboisse JC, Oudart JB, Ramont L, Brassart-Pasco S, Maquart FX. Matrikines from basement membrane collagens: a new anti-cancer strategy. Biochim Biophys Acta. 2014; 1840:2589-2598.

33. Golubovskaya VM. Targeting FAK in human cancer: from finding to first clinical trials. Front Biosci (Landmark Ed). 2014; 19:687-706. 
34. Infusino GA, Jacobson JR. Endothelial FAK as a therapeutic target in disease. Microvasc Res. 2012; 83:89-96.

35. Zhang J, Hochwald SN. The role of FAK in tumor metabolism and therapy. Pharmacol Ther. 2014; 142:154-163.

36. Gahmberg CG, Fagerholm SC, Nurmi SM, Chavakis T, Marchesan S, Grönholm M. Regulation of integrin activity and signalling. Biochim Biophys Acta. 2009; 1790:431-444.

37. Calalb MB, Polte TR, Hanks SK. Tyrosine phosphorylation of focal adhesion kinase at sites in the catalytic domain regulates kinase activity: a role for Src family kinases. Mol Cell Biol. 1995; 15:954-963.

38. Abu-Ghazaleh R, Kabir J, Jia H, Lobo M, Zachary I. Src mediates stimulation by vascular endothelial growth factor of the phosphorylation of focal adhesion kinase at tyrosine 861 , and migration and anti-apoptosis in endothelial cells. Biochem J. 2001; 360:255-264.

39. Kwong LN, Davies MA. Navigating the Therapeutic Complexity of PI3K Pathway Inhibition in Melanoma. Clin Cancer Res. 2013; 19:5310-5319

40. Hernandez-Aya LF, Gonzalez-Angulo AM. Targeting the Phosphatidylinositol 3-Kinase Signaling Pathway in Breast Cancer. Oncologist. 2011; 16:404-414.

41. Gu M, Roy S, Raina K, Agarwal C, Agarwal R. Inositol Hexaphosphate Suppresses Growth and Induces Apoptosis in Prostate Carcinoma Cells in Culture and Nude Mouse Xenograft: PI3K-Akt Pathway as Potential Target. Cancer Res. 2009; 69:9465-7942.

42. Di Zazzo E, Feola A, Zuchegna C, Romano A, Donini CF, Bartollino S, Costagliola C, Frunzio R, Laccetti P, Di Domenico M, Porcellini A. The p85 Regulatory Subunit of PI3K Mediates cAMP-PKA and Insulin Biological Effects on MCF-7 Cell Growth and Motility. Scientific World Journal. 2014; 2014:565839. doi: 10.1155/2014/565839.

43. Hers I, Vincent EE, Tavaré JM. Akt signalling in health and disease. Cell Signal. 2011; 23:1515-1527.

44. Madhunapantula SV, Mosca PJ, Robertson GP. The Akt signaling pathway. Cancer Biol Ther. 2011; 12:1032-1049.

45. Goundiam O, Nagel M-D, Vayssade M. Akt and RhoA inhibition promotes anoikis of aggregated B16F10 melanoma cells. Cell Biol Int. 2012; 36:311-319.

46. Fyffe C, Falasca M. 3-Phosphoinositide-dependent protein kinase- 1 as an emerging target in the management of breast cancer. Cancer Manag Res. 2013; 5:271-280.

47. Li Y, Yang K-J, Park J. Multiple implications of 3-phosphoinositide-dependent protein kinase 1 in human cancer. World J Biol Chem. 2010; 1:239-247.
48. Copp J, Manning G, Hunter T. TORC-specific phosphorylation of mTOR: phospho-Ser2481 is a marker for intact mTORC2. Cancer Res. 2009; 69:1821-1827.

49. Pópulo H, Lopes JM, Soares P. The mTOR Signalling Pathway in Human Cancer. Int J Mol Sci. 2012; 13:1886-1918.

50. Chiang GG, Abraham RT. Phosphorylation of Mammalian Target of Rapamycin (mTOR) at Ser-2448 Is Mediated by p70S6 Kinase. J Biol Chem. 2005; 280:25485-25490.

51. Koo J, Wang X, Owonikoko TK, Ramalingam SS, Khuri FR, Sun S-Y. GSK3 is required for rapalogs to induce degradation of some oncogenic proteins and to suppress cancer cell growth. Oncotarget. 2015; 6:8974-87. doi: 10.18632/oncotarget.3291.

52. Ali A, Hoeflich KP, Woodgett JR. Glycogen synthase kinase-3: properties, functions, and regulation. Chem Rev. 2001; 101:2527-2540.

53. Sun T, Rodriguez M, Kim L. Glycogen synthase kinase 3 in the world of cell migration. Dev Growth Differ. 2009; 51:735-742.

54. Madhunapantula SV, Sharma A, Gowda R, Robertson GP. Identification of glycogen synthase kinase $3 \alpha$ as a therapeutic target in melanoma. Pigment Cell Melanoma Res. 2013; 26:886-899.

55. Aziz SA, Jilaveanu LB, Zito C, Camp RL, Rimm DL, Conrad P, Kluger HM. Vertical targeting of the phosphatidylinositol-3 kinase (PI3K) pathway as a strategy for treating melanoma. Clin Cancer Res. 2010; 16:6029-6039.

56. Gallagher SJ, Rambow F, Kumasaka M, Champeval D, Bellacosa A, Delmas V, et al. Beta-catenin inhibits melanocyte migration but induces melanoma metastasis. Oncogene. 2013; 32:2230-2238.

57. Arozarena I, Bischof H, Gilby D, Belloni B, Dummer R, Wellbrock C. In melanoma, beta-catenin acts as suppressor of invasion through a cell-type specific mechanism. Oncogene. 2011; 30:4531-4543.

58. Collu GM, Hidalgo-Sastre A, Brennan K. Wnt-Notch signalling crosstalk in development and disease. Cell Mol Life Sci. 2014; 71:3553-67.

59. Bouifraden S, Drouot C, el Hadrami M, Guenoun F, Lecointe L, Mai N, Paris M, Pothion C, Sadoune M, Sauvagnat B, Amblard M, Aubagnac JL, Calmes M, et al. Some of the amino acid chemistry going on in the Laboratory of Amino Acids, Peptides and Proteins. Amino Acids. 1999; 16:345-379. 